\title{
The Mexican political fracture and the 1954 coup in Guatemala (The beginnings of the cold war in Latin America)
}

\author{
Soledad Loaeza \\ El Colegio de México \\ maloa@colmex.mx
}

Submitted: 2 September 2014. Accepted: 16 February 2015

\begin{abstract}
This article challenges two general assumptions that have guided the study of Mexican foreign policy in the last four decades. First, that from this policy emerges national consensus; and, secondly that between Mexico and the US there is a "special relation" thanks to which Mexico has been able to develop an autonomous foreign policy. The two assumptions are discussed in light of the impact on Mexican domestic politics of the 1954 USsponsored military coup against the government of government of Guatemala. In Mexico, the US intervention reopened a political fracture that had first appeared in the 1930's, as a result of President Cárdenas'radical policies that divided Mexican society. These divisions were barely dissimulated by the nationalist doctrine adopted by the government. The Guatemalan Crisis brought some of them into the open. The Mexican President, Adolfo Ruiz Cortines' priority was the preservation of political stability. He feared the US government might feel the need to intervene in Mexico to prevent a serious disruption of the status quo. Thus, Ruiz Cortines found himself in a delicate position in which he had to solve the conflicts derived from a divided elite and a fractured society, all this under the pressure of US' expectations regarding a secure southern border.
\end{abstract}

KEYWORDS: Cold war; cardenismo; fracture; anti-Communism; intervention; stability; destabilization

Citation / Cómo citar este artículo: Loaeza, Soledad (2015). "The Mexican political fracture and the 1954 coup in Guatemala (The beginnings of the cold war in Latin America)". Culture \& History Digital Journal, 4 (1): e006. doi: http://dx.doi. org/10.3989/chdj.2015.006

RESUMEN: La fractura política Mexicana y el golpe de 1954 en Guatemala (Los incios de la guerra fría en América Latina).- Este artículo ofrece una discusión crítica de dos presupuestos generales que han orientado el estudio de la política exterior mexicana en las últimas cuatro décadas. Primero, que la política exterior es forjadora de un consenso nacional; y segundo, que entre México y Estados Unidos existe una relación especial que le ha permitido a México desarrollar una política exterior independiente. Ambos presupuestos se analizan a la luz del impacto del golpe militar que patrocinó el gobierno de Estados Unidos contra el gobierno de Guatemala en 1954. En México, la intervención de Estados Unidos en Guatemala provocó la reapertura de una fractura política que había surgido durante el gobierno radical de Lázaro Cárdenas, y que la doctrina nacionalista disimulaba. La crisis guatemalteca la reanimó y promovió movilizaciones que a ojos del Presidente Ruiz Cortines, comprometían la estabilidad política y abrían la puerta a la intervención de Estados Unidos, que consideraba crucial la estabilidad de su frontera sur. Ruiz Cortines estaba en una situación muy delicada, porque tenía que resolver los conflictos de una sociedad fracturada y de una elite dividida, bajo la presión de las demandas de estabilidad de Washington.

PALABRAS CLAVE: Guerra fría; cardenismo; fractura; anticomunismo; intervención; estabilidad; desestabilización

Copyright: (C) 2015 CSIC This is an open-access article distributed under the terms of the Creative Commons AttributionNon Commercial (by-nc) Spain 3.0 License. 
In June 1954 the CIA sponsored the overthrow of the Guatemalan President Jacobo Árbenz. This intervention is an established historical fact. In 1999 President Bill Clinton in a visit to Guatemala said: "Support for military forces and intelligence units which engaged in violence and widespread repression was wrong, and the United States must not repeat that mistake" (Barrett, 2011: 23). This action was similar to the covert operation the Eisenhower administration undertook the year before against President Mossadegh in Iran. In Washington the same cause explained both cases: Soviet expansion. The relevance of the Guatemalan episode lies in that it is at the origin of decades of instability and internal strife in Latin American countries. In Guatemala itself it was the beginning of more than four decades of military rule and repression (Blanton, 2008; Cullather, 2006; Rabe, 2012).

Washington's aggression against a constitutional government that had been democratically elected triggered a wave of protest throughout the region soured inter-American relations and gave a dramatic meaning to the notion sphere of influence. Protests against the US dissolved shortly after Árbenz' downfall. However, the intervention left a lasting mark on the perception Latin Americans had of the United States, and on the internal dynamics of the countries of the region. As Stephen G. Rabe says, "Guatemala served as the training ground for subsequent US interventions in countries like Cuba, Brazil, British Guiana and Chile." (Rabe, 2008: 53). It also conveyed to Latin Americans the message that the Good Neighbor policy belonged to the past.

The impact of these events on Mexican domestic politics is rarely examined, (Buchenau, 2004; Pellicer, 1965 1966; Robinson, 1987) even though almost ten years later, the Cuban Revolution had a similar effect. This experience by contrast, has been a subject of interest to many scholars (Covarrubias, 2008; Fenn, 1963; Keller, 2012; Pellicer, 1968; Pellicer, 1972). In Mexico, the operation against Árbenz in 1954 produced reactions analogous to those that accompanied the Cuban events: it stirred up protests among university students and teachers; divided the political elite, and within the middle-classes it reopened a political fracture that had first appeared in the thirties. Former President Lázaro Cárdenas was at the heart of this division. His government's radical policies (19341940) precipitated the politicization of Mexican society, instigating an ideological confrontation between socialists, nationalists, Catholics and Communists. The conflicts were so severe that the country seemed to be on the brink of a civil war. The Second World War introduced a truce that was the basis of long-term stability.

The political fracture that split Mexican society and elite at the end of Cárdenas' term of office was reopened by the cold war. This was among the most salient effects of the 1954 crisis in the US-Guatemala relation. The conflict replicated the USSR/US rivalry at the local level. In Mexico it also exposed the persistence of the antagonism that opposed cardenistas and anti-cardenistas. Thus, in the Summer of 1954 the political debate in
Mexico was set by an external issue, the US intervention in Guatemala.

In March 1954 the X Inter-American Conference took place in Caracas. At issue was the presumed Communist influence on the Guatemalan government. Secretary of State, John Foster Dulles' intention was to condemn the Guatemalan government and prepare a collective intervention against it. Mexico's position at this conference seemed to adhere to a tradition of autonomy in foreign policy. The Mexican delegation did not give in to the US pressure, and when the anti-Communist resolution was submitted by the US delegation to the assembly, Mexico abstained from voting. For Ruiz Cortines, this stance did not imply a rejection of Washington's anti-Communist crusade or the commitment to a continuous support of the Guatemalan reformist government. After Árbenz fell, the Mexican President distanced himself from the Guatemalan exiles' and took harsh measures against Communists in Mexico. What is the explanation for this apparent contradiction? What was the impact of the cold war on Mexican politics? What were the Mexican president's goals? What was the link between internal and external policies?

Two broad assumptions guide most of scholarly research on Mexican foreign policy of the second half of the twentieth century: first that foreign policy is a source of national consensus (Ojeda, 1976: 105; Meyer, 2010). Second, that Mexico and the US had a "special relationship", an "understanding". According to which the two countries "agreed to disagree" on matters of international politics that did not involve strategic interests of either country. This agreement would be the basis of a relatively autonomous Mexican foreign policy (Ojeda, 1976: 93).

The Guatemalan episode of 1954 disproves both assumptions. First, Mexican public opinion and the elite were divided. There was sharp disagreement on the government's policy towards Guatemala, and on the extent of Communist influence in the Árbenz government. Second, at the end of the crisis President Ruiz Cortines joined Washington's policy intended to "extirpate" Communist influence from the hemisphere.

The assumption that foreign policy creates national consensus is difficult to sustain when examining its implications. First, it implies that internal stability depends on it. There is no evidence to support this claim that overestimates the meaning of foreign policy for Mexican society. At the same time, it underestimates the divisive effects of international politics in a politically diverse society. For instance, in 1936 Mexican public opinion was profoundly divided regarding the support President Lázaro Cárdenas gave to the Spanish Republic, again in 1942, on the declaration of war against the Axis, and after 1945 there was no unanimity with respect of the post- war alliance with the US (Sola Ayape, 2014; Archivo Manuel Gómez Morín, [AMGM] Instituto Tecnológico Autónomo de México). ${ }^{1}$ In spite of bitter disagreement within Mexican society, internal balances did not collapse. Foreign policy was not conducive to internal reconciliation, but the nationalist discourse and the PRI hegemony dis- 
simulated the differences. Secondly, between Mexico and the US there was no long-term "agreement to disagree", rather short-term bargains renewed in accordance with the conditions of the immediate context. In 1954 the margin of maneuver of the Mexican President was defined by Eisenhower's narrow interpretation of Soviet aims and strategy. This margin was broader in the context of John Kennedy's less intransigent and exacting foreign policy.

Ariel Rodríguez Kuri claims that President Ruiz Cortines represents the apex of the success of Mexican authoritarianism. According to him, Ruiz Cortines was the beneficiary of a consolidated political consensus achieved thanks to political stability and sustained economic growth (Rodríguez Kuri, 2008). The focus of Rodríguez Kuri's analysis is the presidency as an institution persistently threatened by local caciques or dissidents from the revolutionary elite. However, by the beginning of the fifties it had finally stabilized. A broad perspective of the political system outbalances Rodriguez Kuri's consensus and exposes fissures, cracks and cleavages concealed by an imaginary all-powerful Presidency.

Ruiz Cortines' ambivalence or lack of enthusiasm for the reformist policies the arbencistas called the "Guatemalan primavera" was primarily a defensive reaction that indicates profound fractures in Mexican society. The President's priority was the preservation of political stability. Ideological antagonisms, socioeconomic and regional differences divided Mexican society. Stability was fragile in a fractured society where the elite in power was torn and the nationalist call seemed insufficient to build consensus. The Guatemalan crisis increased the destabilizing potential of these divisions. There were other causes of discontent, such as the Partido Revolucionario Institucional, PRI,'s virtual monopoly of political participation, rigged elections, inflation and the exasperating poverty of rural Mexico. The conditions of the country were difficult the first three years of Ruiz Cortines' term of office: economic growth slowed down, while demographic growth accelerated, disagreements derived from a conflicting presidential election in 1952. Alienated segments of the middle classes from the government, and inflation created unrest among workers' unions.

The Mexican President feared that the extension of the protest against US intervention would lead to a large and complex mobilization. Ruiz Cortines anticipated a conservative reaction to an emboldened left. Such a development could easily lead to the proliferation of protests, and to an anti-government mobilization. In that event, the powerful neighbor might be tempted to intervene to reestablish in Mexico a stability that was important to its security. Mexico's apprehension was not groundless since interventionism was a central component of the US cold war policy. The Guatemalan episode confirmed the observation of a US diplomat, that Latin Americans were more afraid of US interventionism than of Guatemalan Communism. ${ }^{2}$

Ruiz Cortines' Guatemalan policy sought to satisfy the demands both of the left-wing of the official party, and of the conservatives that joined anti-Communist organizations and demonstrations. The President would defend self-determination when he addressed the Mexican left, and attack Communism when talking to Mexican anti-Communists, the private sector or the Catholic hierarchy. At the same time, south of the border the US needed a stable and reliable neighbor. President Ruiz Cortines had to guarantee Mexico's political stability to the US government. The differing positions and views of relevant political actors restricted Ruiz Cortines' options. He tried to keep a delicate balance between antagonistic pressures by playing what could be seen as a duplicitous game.

President Ruiz Cortines' policy towards Guatemala has been harshly criticized. Jürgen Buchenau describes it as "the abandonment of revolutionary principles" achieving a "feeble balance"; (Buchenau, 2004: 119-120). Nancy Robinson attributes the "lukewarm support" of Arbenz to the predominantly conservative atmosphere of the country and to "traditionally conflicting" relations between Mexico and Guatemala; (Robinson, 1987: 232). Buchenau and Robinson argue that Ruiz Cortines' policy was designed to accommodate the US and the Mexican private sector's pressures. Their conclusion is correct but their analyses are incomplete. The restrictions weighing upon the presidential decision-making derived also from divisions within the political elite, and from the opposing views of cardenistas and anticardenistas.

The Mexican President's goals were contradictory: he had to reconcile internal demands with external pressures, among which the US pressure was the most threatening. US strategy against the expansion of Soviet influence in Latin America destabilized the regional status quo and the internal balance of the countries where the US intervened. The battle against Communism shifted internal balances in these countries, and this produced the destabilizing consequences the alleged Communist offensive the US was trying to attack. The repercussions of this strategy were more disturbing than the impact of the policies it sought to check. The Mexican experience was exceptional among Latin American countries in that the government succeeded in keeping the US away from the country's domestic politics. Thus, a powerful cause of instability, direct US intervention, was absent from Mexican politics.

This article shows, first, that Mexican foreign policy was another source of division within Mexican society because it was a reflection of an internal fracture; and, secondly, that political stability depended on the government's ability to stop the mobilization of opposing groups. Mexican foreign policy could be charged of having two faces because it sought to dissolve tensions between antagonistic forces: cardenistas and anticardenistas. Political stability depended on the agreement of the left, as much as on that of conservative segments of public opinion, the anticardenistas, the Catholic Church and business organizations. Ruiz Cortines' needed also to maintain a cordial relation with the US. He also had to convince the US government that he had the capacity to 
guarantee stability, and persuade the US agencies and representatives that he could do so without US help.

In order to address this hypothesis, I begin by describing the impact of the cold war in Mexico and the rise of conservatism as a general atmosphere that enveloped the country; a section of this first part is dedicated to the cardenismo/anticardenismo fracture; secondly, I explore the US -Mexico relation within the framework of the US cold war Latin American policy, and the third part discusses President Ruiz Cortines' response to the Guatemalan crisis and its repercussions on the strategy of internal political actors.

\section{THE COLD WAR IN MEXICO}

The transformation of the US into a superpower was the most momentous change affecting Mexico in the post-War period. A century after the 1847 war, the significant asymmetries that in the past were already significant in 1946 became incomparable. In terms of population alone, in that year Mexico had a population of 23 million; the United States had 145 million and was the world's leading industrial, economic and military power. Its size, geographical proximity and its offensive capabilities represented a threat to Mexico, whose government lived in constant apprehension of its neighbor's propensity to intervene in the domestic politics of other countries. The cold war accentuated this proclivity.

The cold war was a global phenomenon that in each country took the features of the local environment (Fein, 2008: 204). In Mexico it gave rise to a powerful conservative atmosphere in a context of rapid social change, population growth, weak institutions and pronounced social inequalities. These processes and the tensions of a world that seemed to be on the verge of a nuclear war justified the concentration of power and the centralization of decision-making processes. Thus, the international context contributed to the authoritarian regime's consolidation. Three fundamental pieces shaped the political system: a centralized State, the presidency and the PRI. The hegemonic party was the main instrument of political control and the pillar of an extended clientelistic structure, that was central to the "diffuse support" many Mexicans gave their political system (Coleman, 1976). This system discouraged political participation because stability rested mostly on conformity, controlled participation and repression.

In Mexico, the international context antagonism between Liberal Democracy and Totalitarian Communism was juxtaposed with existing political divisions namely the political fracture that separated cardenistas and anticardenistas. The cold war became the framework of reference for the Communist Party and for the Catholic Church. It redefined their position in the political system and the terms of the political debate, and it altered the balance of power. This framework helped the post-war Presidents undermine the cardenista coalition that up until 1948 included peasants' and labor organizations that remained loyal to cardenismo, and a significant segment of the intellectual, elite and of the middle classes. It also included a current of the PRI represented by Vicente Lombardo Toledano, a successful union leader. In 1936 Lombardo founded the powerful Confederación de Trabajadores de México, CTM, Confederación de Trabajadores de América Latina, CTAL, that in 1945 represented 300 thousand workers.

In the bipolar world, the ascent of the US was also felt in the realm of culture and ideas. In Mexico it gradually became predominant at the expense of the European influence that until the Second World War had been a protecting shield against US overwhelming power. Many Mexicans resented this influence. PRI ideologues conceived a nationalist doctrine intended to resist the appeal of US mass culture, solidify the Mexican identity, and foster traditional values. The nationalist doctrine was also meant to give ideological support to the regime. Inevitably, it had a significant component of antiUS attitudes that could easily turn into anti-Imperialistic manifestations, and often it carried a reflex reaction to side with the US adversaries. Therefore, anti-US protests could sound as pro-Communist or pro-Soviet attitudes and statements. However, Mexico adhered voluntarily to the anti-Communist crusade the US President, Dwight Eisenhower, launched as soon as he took office (1952-1956).

The increasing influence of US culture was a matter of concern for Mexican elites. In 1947, Daniel Cosío Villegas, the liberal historian and political commentator, wrote that US' influence crushed Mexico. It changed everything: food, fashion, political ideas, the language. It was like the Christian God: almighty and everywhere (Cosío Villegas, 1966, I: 202).

The growing influence of the Catholic Church was a reaction to the US cultural influence, but the Church also played a significant role of social control. Historically, it had been critical of the influence of the "American way of life", of the liberal habits of women and of the frequency of divorce in US society. Nevertheless, after 1945 the Church and the US embassy met in the anti-Communist crusade, although there was a fundamental difference between anti-Communism in the US and anti-Communism in Mexico. The former's emphasis was on civil liberties, by contrast, the latter was a patriotic defense of religion and the family.

The change in the position of the Catholic Church on the political stage had a decisive impact on Mexican society and domestic politics. The 1917 Constitution contained a number of anticlerical dispositions intended to subordinate the Church to State authority and to limit its influence on society (These dispositions were eliminated in 1991). In the years of revolutionary radicalism, the Church was persecuted and fought a three-year war against the State (1926-1929). However, when Mexico entered the Second World War, the Church responded to the government's call for national unity and was incorporated into the post-revolutionary regime.

The presumed "Communist offensive" and the vigorous anti-Communist crusade of the Vatican inspired a 
religious revival. Catholic propaganda flooded Mexican homes. In violation of constitutional dispositions forbidding the political usage of religion and the clergy's participation in politics by the 1940's Church authorities became regular guests at official ceremonies. A number of Vatican representatives visited Mexico; closer ties developed between the Catholic Church in Mexico and US Catholics. The Archbishop of New York, Francis Cardinal Spellman, assumed the functions of Vicar of the Vatican in Latin America. The streets of Mexican cities provided the stage for religious celebrations. It was no secret that ecclesiastical authorities maintained constant exchanges with the President. In a 1955 interview with Time Magazine, Archbishop Luis María Martínez declared "Faith is stronger than law", he added that the only thing missing was a constitutional reform. ${ }^{3}$ (Time, 09/ May/ 1955).

The strength of conservatism did not result in the development of a strong Catholic party. The Catholic Church could be the center of an alternative to the PRI, but its relations with the State were so close and complex if undefined, that Catholic authorities would not risk a confrontation. Thus, in Mexico Catholics remained tied to an extreme traditionalism that preached depoliticization and adherence to the nationalist doctrine (Loaeza, 1988: 160-169). The close collaboration between Church and State hampered the development of an independent organization that would channel the institutional participation of right-wing sympathizers.

In this conservative setting, few objective elements justified the anti-Communist alarm. The relations between Mexico and the Soviet Union were rather poor. Mexico was the first Latin American country to establish diplomatic relations with the Soviet regime in 1925, however, they were interrupted after the Comintern directed the Partido Comunista Mexicano, PCM, to undertake revolutionary actions against the Mexican government in 1930 (Cárdenas, 1993; Spenser,1999). Relations were reestablished during the war. From then on Mexican Communists were consistently dependent on the "official left" represented by cardenismo and Lombardo Toledano.

The Mexican Revolution was the main obstacle to the development of Communism. The space this political force could have filled was taken by what was called revolutionary radicalism as practiced by President Cárdenas. During his term of office, the PCM followed the Popular Front strategy established by the Comintern, thus becoming a minor ally to the Partido Nacional Revolucionario, PNR, in power. The Central de Trabajadores de México, CTM, founded by Lombardo Toledano in 1936, virtually monopolized the control of workers' organizations. According to documents in the Soviet archives, for the Soviet government Lombardo was the real leader of the Mexican working class. ${ }^{4}$ US and British intelligence considered him a "dangerous" and powerful man, the number 1 Soviet agent in Latin America (Spenser, 2010). His political goals, his technique and the propaganda he disseminated were "identical" to those of "active Communist units". 5
The 1950's was a difficult decade for Mexican Communists. The PCM agonized for lack of resources, but also because of the relentless persecution by the government against its members. Police forces raided regularly the party's meetings and offices, and its leaders were incarcerated. The organization was further weakened by internal disputes and purges. According to a 1948 CIA report the number of card-carrying Communists in Mexico City was uncertain but not higher than one thousand. ${ }^{6}$ In 1951 the party failed to gather the 30 thousand membership the law required, therefore, it lost official registration. In 1958 it had less than 5 thousand members in the whole of Mexico, whereas the CP in Argentina had 70 thousand members, in Brazil 50 thousand and in Cuba 12 thousand. ${ }^{7}$ Mexican Communists depended on former President Cárdenas and Lombardo Toledano neither of which belonged to the party, however, both had direct access to the Soviet Communist party and to the Soviet government.

In the eyes of US intelligence agencies, Mexico was not an entirely reliable ally. First, the President, the PRI and union leaders made constant references to the Mexican revolution in an equivocal manner in the cold war context. Also, the line separating nationalism from antiUS statements and policies was tenuous. The main complaint the CIA had on Mexico's anti-Communist battle concerned the role the country played as a meeting point for Communists from all Latin America and other countries. ${ }^{8}$ In 1948, according to the agency's report, the most important international Communist meetings outside the USSR were held in Mexico with delegates from Europe and Latin America in attendance. There they took decisions which "threatened the strategic interests of the United States." "According to the report, the Mexican government did not help the Communists, nevertheless Mexico was "the main tactical area of Communism in the Western Hemisphere". ${ }^{10}$ (NACP, CIA, 1949). However, the authors of this report missed that by 1954 revolution in Mexico was a historical chapter not a political option.

\section{A fractured elite and a divided society: Cardenismo and anti-Cardenismo}

President Lázaro Cárdenas revitalized the Mexican Revolution that in the twenties had fallen into the hands of the last generation of generals who had fought in the civil war. He mobilized workers and peasants; encouraged their organization, began an extensive land reform, introduced labor legislation, and nationalized the oil industry. The image of President Cárdenas became forever tied to the defense of the underprivileged. His policies were associated to a strong State, anticlericalism, Statecontrolled schools and expropriations. Cárdenas was popular with workers and peasants, but he was unpopular with the bourgeoisie and large segments of the middle classes. The roots of the most consequential political fracture of XXth century Mexico are to be found in his administration (Knight, 1994). 
The positions and proposals of cardenistas were more consistent and better articulated than those of anti-cardenistas who were a heterogeneous lot: some of them were prominent members of the private sector or their employees; the majority upheld Catholic traditions rejecting the Revolution's legacy of policies and institutions. Anticardenismo marshalled the PAN, the ultraconservative Unión Nacional Sinarquista, UNS, and other Catholic and business organizations. These groups may have been large but their lack of organization made them relatively weak. They never found a leader similar to Cárdenas or Lombardo to unify them. Besides, they tended to shun political participation and only gained some coherence in times of crisis, or when they were facing a challenge, such as the return of Cárdenas and the organization of the left.

The image of Lázaro Cárdenas remained firmly rooted in many Mexicans' imagination even after he left office. He was influential with politicians and government officials. He often intervened on behalf of workers or peasants, to demand the President to help solve a conflict involving unions or agrarian leagues. ${ }^{11}$ However, he was a contradictory figure: he challenged presidential authority, and was at the heart of the political fracture that eroded the PRI's hegemony. At the same time, Cárdenas was at the center of the official party's legitimacy given that he was an essential protagonist of the post-revolutionary State.

Cárdenas political comeback was a reaction to Washington's increasing hostility against reformist governments in Latin America, and to the Eisenhower's administration proclivity to intervene, plan covert operations, subversive actions and negative propaganda campaigns. He believed that US hegemony was destroying national sovereignty in Latin America. The former President became the self-appointed representative of a growing anti-US sentiment shared by many Mexicans who thought that the US exploited Latin American countries and gave nothing in return. This attitude was fed by the persistent refusal of the US to support Latin American countries' economic development. ${ }^{12}$ Cárdenas' criticisms of US policy appealed to many Mexicans who had been affected by the government's restrictive economic policy, or for whom the significant increase of foreign direct investments was a cause of alarm. ${ }^{13}$

Also, US cold war policy was probably one of the reasons why the former President became close to Latin American Communists and Soviet-sponsored organizations. This move was somewhat surprising because when he was President he kept the Communists at a distance (Carr, 1982: 62-63). Nevertheless, he was a prudent politician. As already said, he avoided confrontation particularly with the President. The wish to remain in good terms with the President may be the reason he spent so much time and energy in international issues and eluded domestic affairs. Latin American themes enabled Cárdenas to become a leader of opinion within and outside the PRI. His followers shared his criticisms of the conservative policies of his successors in the presidency. In all likelihood, President Ruiz Cortines preferred Cárdenas participating in discussions on the arms race and world peace, than discussing minimum wages in Mexico. This Presidential strategy of leading Cárdenas to international issues had long-term consequences on the relationship of the Mexican left and foreign policy, making it an area of policy-making identified with cardenista postures. Also, an institutional pattern was developed that set Mexico's commitment to democracy, or any progressive cause, in the realm of foreign relations. For decades, the official left tended to concentrate in this area, to specialize in these matters and to see foreign policy as its territory. This "transaction" was reached at the expense of consistency of an authoritarian regime which in the outside world fought for democracy.

Throughout the second half of the forties, Cárdenas extended his leadership to Central America. He sought to articulate a nationalist and anti-imperialistic defense of Latin American countries. In doing so, he became involved in a dense network of contacts with foreign organizations, many of them linked to international Communism. In 1948 he was elected member of the Honor Committee of the Congress of Trade-Unions Unity, and the Cuban Communist leader, Juan Marinello invited him to be vice president of the World Peace Conference, a Soviet organization (NACP, CIA, 1954). ${ }^{14}$ In 1956, Cárdenas was awarded the Stalin Peace Prize by the Soviet government.

Cárdenas' return to the political stage assembled his adversaries, those who thought he personified the Communist influence. In the fifties, the two most important newspapers in Mexico City, Excelsior and El Universal, sustained a prolonged and violent anti-cardenista campaign (Servín, 2004). The UNS spearheaded a violent charge against him, accusing him of planning a return to power only now as a Moscow agent. The conservative weekly La Nación offers an ample repertory of anti-Cárdenas attacks. In June 1954, in the midst of the Guatemalan crisis, the magazine stated that Cárdenas' utmost interest was "state-sponsored, left-wing Communism". It also referred to his government's policies as "cruel and inept experiments". ${ }^{15}$ La Nación explained that Cárdenas was taking advantage of events in Guatemala to agitate in Mexico which it said, he flooded with declarations and statements, while stirring unrest in the countryside. ${ }^{16}$

The cardenismo/anticardenismo antagonism transcended Cárdenas himself and his term of office. It became a historical fracture, a long-standing feature of the Mexican political landscape of the second half of the XXth century and a pivot for a wide range of political forces and options. At times of intense politicization, the fracture became visible and framed the conflict of the moment. In 1954, it played its part in the Communist/antiCommunist dispute; in 1961, it provided the background for the founding of the Movimiento de Liberación $\mathrm{Na}$ cional, inspired by the Cuban revolution. In 1988, when it 
finally split from its roots, the PRI, it articulated the leftwing opposition to neo-liberal policies. In the XXIst century cardenismo continues to be a reference for all political forces.

\section{MEXICO IN PRESIDENT EISENHOWER'S LATIN AMERICAN COLD WAR POLICY}

At first glance, the post-war international order appeared not to have significantly altered relations between countries in the hemisphere; it had simply consolidated the United States' hegemony and accentuated the region's relative isolation from the rest of the world. In 1945, the rule of the Monroe Doctrine was acknowledged as a legitimate reference for all countries in the continent - except Canada - at the 1945 Chapultepec Conference in Mexico City. The Act of Chapultepec consecrated the Doctrine on the assumption that anti-Communism was the cornerstone of a political identity shared by all nations in the Hemisphere.

Because of his military background Eisenhower's foreign policy perspective was deeply influenced by geopolitical and strategic considerations. His view was embedded in the Monroe Doctrine. ${ }^{17}$ Anticommunism took a predominant place in Eisenhower's thinking. It led his administration to an "unabashed embrace of anti-Communist military dictatorships and its unwillingness to criticize, however mutedly, rampant political and civil repression in Latin America." (Rabe, 1988: 40-41). At the same time, the acknowledgment of Latin America's strategic importance did not make Eisenhower change his view regarding the economic development of the region. He firmly believed it should rely primarily on resources supplied by trade and private investment (Rabe, 1988: 66). Consequently, the Eximbank long-term lending was frozen, "the banks development loans in Latin America fell from 147 million in 1952 to 7.6 million in 1953." (Rabe, 1988: 66)

Eisenhower's policy towards Mexico was nuanced in that he would seek to understand this country's needs before acting on uninformed assumptions, as it apparently happened in other countries. Guatemala seems to be an egregious example of this kind of policy-making. In this respect Mexico held a privileged position. Eisenhower would often ask the US ambassador directly for information about the Mexico's internal situation by-passing the State Department. Thus, at this particular stage of the cold war, the Mexican government could use the US fear of Soviet expansion to its advantage. It leveraged the country's geographical location within the North American security perimeter to ensure a different treatment to that given other countries in the region. This would be the basis for the "special relation" between the two countries. At the same time, the US-USSR rivalry hardened the restrictions on "the country's freedom of political action" (Ojeda, 1974: 92). The deterioration of the relation between the superpowers, the intensification of international tensions and the threat of a nuclear war inhibited Mexico's diplomatic activity.
The Mexican government adopted two strategies to cope with the power of the United States. First, it assimilated the main restrictions deriving from territorial contiguity, as if these limitations were self-imposed. For example, regarding international alliances Mexico knew it could never approach the Soviet Union. It also acknowledged that socialism was not an alternative for a country that was the neighbor and weak ally, of the most ferocious adversary of that ideology and political regime. ${ }^{18}$ Secondly, the nationalist doctrine developed by the PRI included a commitment to democracy. As a result, anti-Communism took a prominent place in the official PRI doctrine. This addition turned out to be useful for the government that was seeking to weaken the cardenista coalition, many of whose members were identified as Communists.

At the time, democracy was understood as a longterm process. Washington accepted the Mexican regime as a "democracy in the making" the more praiseworthy because it was able to maintain political stability. Eisenhower repeatedly talked about his wish to foster cooperation with Mexico, which he considered different to other Latin American countries, simply because it shared with the US a border stretching more than 1800 miles. This fact bore a special meaning for a military man, who was also fighting a war, of a fundamentally diplomatic and ideological nature, but one that could become an armed conflict at any moment. Under those conditions, it was clearly advisable to maintain good relations with a neighbor whose territory could be useful in the worst case scenario. ${ }^{19}$

In October 1953, when the preparations for the coup against Árbenz were gathering pace, the Presidents of Mexico and the United States met at the inauguration of the Falcon Dam on the border between Tamaulipas and Texas. In his welcoming speech, Eisenhower compared the two countries with two friends who shared "the kind of friendship that seeks-seeks earnestly and persistently to understand the viewpoint of the other, and then labor with sympathy and with all that is in the heart to meet the viewpoint of his friend." (The New York Times, 20/ 10/ 1953). He offered Mexico help and talked about the country's specific needs of technical assistance, educational opportunities and capital. Ruiz Cortines' public response was a defense of general and abstract principles: he alluded to a threatened international peace. He also spoke of national sovereignty and self-determination as priority issues in the Mexican agenda, as if the ghost of intervention was flying over the friendly meeting.

The press reports suggest that President Eisenhower was speaking the language of cooperation, but the Mexican President seemed unimpressed. If the US President was indeed offering Mexico a program of economic aid, this meeting was a lost opportunity to give the US-Mexico relations a new direction and a wider scope. No meaningful dialog took place between the two Presidents. Instead parallel monologues prevailed. There was just one subject on which both agreed explicitly: the need to fight Communism and the preservation of Mexican political stability that Eisenhower was prepared to bolster. ${ }^{20}$ 
This political and ideological alliance was the foundation of an essentially cordial bilateral relation. In Secretary Dulles' opinion a balance of expectations had been struck between Mexico and the US: "We know what to expect from Mexico and understand her limitations. The same is true of Mexico's attitude towards the United States although it is traditionally colored by vague suspicion of our motives." 21 John Foster Dulles' views on Mexico seem surprisingly balanced and well-informed. ${ }^{22}$ At this time of general paranoia, the Mexicans' ambivalent attitudes and policies toward foreign Communists, or the government's defense of State's intervention, did not disturb the cordiality between the two countries. According to Dulles, Mexico could not see the seriousness of the Communist threat, because it had "a tradition of extreme liberalism." He believed the Mexican Revolution had socialist tendencies, but that it was neither Marxist nor had a connection to the Soviets. Also, in his opinion, the PRI was committed to capitalism and he concluded "there is little doubt that in time of crisis Mexico would be on our side." (FRUS, 1952-1954: 1351). John Foster Dulles' analysis of the Mexican situation reveals surprising restraint.

\section{Mexico in the face of US intervention in Guatemala}

According to the Mexin Ambassador to the OAS, Luis Quintanilla, the covert operation against the Árbenz government was a public secret (AGE, SRE, Exp. Luis Quintanilla, 17/ 01/ 1955). It was in everybody's minds and lips since 1952; the White House, the Department of State, and Congress were involved. US senators "knew of the operation before, during and immediately after its occurrence." (Barrett, 2011: 24). Their position was "that the US government should do whatever it might take, short of outright war, to stop ongoing 'Soviet aggression' in Central America." (Barrett, 2011: 24). The US press openly discussed the administration's plans to respond to the challenge posed by the Communists influence in Guatemala. In January 1954, the new US Ambassador in that country, John Peurifoy, declared to the press that his country would intervene unilaterally in Guatemala if the situation continued to deteriorate: "Public opinion in the U.S. might force us to take some measures to prevent Guatemala from falling into the lap of international Communism. We cannot permit a Soviet republic to be established between Texas and the Panama Canal." ${ }^{23}$

Mexico was compelled to take a stand at the X InterAmerican Conference the proceedings of which were held in Caracas from March 1 to 28, 1954. President Árbenz had included members of the Communist party in his cabinet, had started an agrarian reform that hurt the interests of the oligarchy and the United Fruit Company. In the eyes of the CIA and the Department of State these measures jeopardized the Hemisphere's stability because they opened the door to Soviet influence.

Many signs indicated that the removal of Árbenz's government was imminent. The meeting in Caracas was scheduled to examine economic issues; however, Secre- tary Dulles used it as a platform to condemn Communism and the Guatemalan government, and to prepare a collective intervention. It was the intention of the Resolution advanced by the US delegation at the conference, to achieve both ends. At the plenary session of March 8, the Mexican Secretary of Foreign Relations, Luis Padilla Nervo, answered to Secretary Dulles' Resolution defending the principles of self-determination and non-intervention. His arguments were clear and consistent, but they were presented in general and abstract terms, never referring to Árbenz' government or Guatemala, in particular. ${ }^{24}$ The Mexican minister pointed out that the US delegation Resolution was against the Mexican constitution and paved the way for foreign intervention in domestic affairs. He proposed two amendments: the first presented "International Communism" as any other political doctrine that did not by itself represent a threat and had no attachments to any particular country; and the second sought to preserve the principle of national sovereignty leaving the terms of the anti-Communist combat to the constitutional rules of each government. The assembly rejected both amendments.

Over the course of two weeks, the Secretary of State worked tirelessly to push through, with the largest possible number of votes, Resolution XCIII, "Declaration of Solidarity for the Preservation of the Political Integrity of the American States against International Communism Intervention". ${ }^{25}$ The Resolution stated that "the domination or control of the political institutions of any American State by the international communist movement, extending to this hemisphere the political system of an extra-continental power, would constitute a threat to the sovereignty and political independence of the American States," endangering the peace of America (Department of State, 1954: 8-9). The Resolution was voted on March 13. It passed with 17 votes in favor, two abstentions Argentina and Mexico ${ }^{26}$ — and Guatemala's solitary vote against. Practically all of the delegates agreed that Communism had no place in the hemisphere, but they also unanimously rejected the interventionism that was implicit in the proposed resolution. ${ }^{27}$

\section{The Mexican game}

In normal circumstances, Mexican public opinion was indifferent to international politics. But in the Summer of 1954 it woke up to the cold war tensions of the Guatemalan Crisis and the mobilization of a leftist minority demanding the government to help Árbenz. Their cause did not win unanimous support. Some believed that the Guatemalans had been reckless to openly challenge the US. Others thought the small country was the victim of a subversive plan. There were those who questioned the idea of foreign intervention and saw the conflict as a civil war.

La Nación charged the "creole communists" of seeking to relinquish Mexico to International Communism. It further denounced the existence of Communist cells in the university and in the Ministry of Foreign Affairs. ${ }^{28}$ (La Nación, 20/ 06/ 1954). After the Guatemalan rebels 
attack against the government, the president of the PRI, General Gabriel Leyva Vázquez stated “...the PRI can declare categorically that democratic symbols are Mexico's banner and that we are against any idea or proposition contradicting those symbols. Thus, the party rejects Communism and any other totalitarian system." ${ }^{29}$ As Manuel Gómez Morín wrote in June 1954, the invasion of Guatemala was "the most important issue for Mexican public opinion today." (La Nación, 20/ 06/ 1954). Vicinity, the fear of Communism and the likelihood of the intervention of US troops would explain the unusual interest raised by the crisis.

President Ruiz Cortines would have preferred to remain on the sidelines and observe the events rather than to involve himself in the crisis. Nevertheless, geography and the Mexican left imposed themselves. The country was restless. A combination of cardenistas and other discontented groups could favor the articulation of protests that had other motivations: inflation, the dire conditions of the agriculture and farmers, low wages, labor unions unrest. The government followed different strategies to meet the potential challenge, among them the sponsorship of "independent organizations" that confronted the left. However, they were nothing more than a label. For instance, the "First Congress against Soviet Intervention in Latin America" was inaugurated in Mexico City at the beginning of June. In addition to the participants who came from all Latin American countries, the Franco government sent a delegation even if Mexico did not have diplomatic relations with the Spanish dictatorship. In the opening speech of the Congress, Arturo Amaya, who was also secretary of the Sociedad Pro-Liberación de Guatemala, thanked President Ruiz Cortines for his political and financial support. ${ }^{30}$

On June 17, Guatemalan rebel troops crossed the border from Honduras to their country under the orders of Colonel Carlos Castillo Armas. They had the support of Ambassador Peurifoy, and of a psychological offensive that made Guatemalans believe that the operation was backed by a much larger military force. Called to the defense of the government, the Guatemalan army hesitated and fearing the arrival of the US marines it abandoned President Arbenz (Gleijeses, 1992: 329-339). On June 26, the press announced his resignation. ${ }^{31} \mathrm{He}$ and his family took refuge in the Mexican embassy.

The Arbenz family's decision to seek asylum in the Mexican embassy was not surprising. Mexico held a respectable tradition of political asylum that was the pride of many members of the Foreign Service; the Mexican revolution was always a reference and a model to the Primavera guatemalteca, mainly the agrarian reform, Mexican engineers having participated in its design. The Mexican left had supported Árbenz from the start, under Lázaro Cárdenas leadership. Nevertheless, arbencistas may not have realized that in the eyes of many Mexicans and of US agencies, this support was proof of their subservience to the Soviet Union.

Vicente Lombardo Toledano was often a guest of the Guatemalan government, and he delivered inflammatory speeches against US imperialism at multitudinous public meetings. ${ }^{32}$ (NACP, CIA, 1951). His career as union leader peaked during Cárdenas term of office. For the Soviet Union Lombardo was the true leader of the Mexican working class. Paradoxically, this closeness of Lombardo's to the Soviet Union limited his alliance with Cárdenas who staunchly defended self-determination.

The support of such influential political leaders led Árbenz to believe that solidarity could be organized between governments of revolutionary origin. ${ }^{33}$ Immediately after the invasion, former President Cárdenas sent a letter to Ruiz Cortines suggesting he mediates in the conflict (Buchenau, 2004: 136). He refused. It was understandable. President Ruiz Cortines was certain that the Junta headed by Castillo Armas would decline the offer, and that it could have a negative effect on the relation with the US. The President did not respond to Cárdenas and Lombardo's entreaties. The Mexican government would defend Guatemala from the trenches of multilateral diplomacy.

There were other signs of support from the World Trade Unions Federation, WTUF; from Lombardo Toledano in the name of CTAL; university students and teachers took to the streets, manifestos were published in the papers. However, the echoes of these protests did not go too far because, according to the French paper $\mathrm{Le}$ Monde, the Mexican press did not report them. ${ }^{34}$ For over two months, the Mexican embassy in Guatemala sheltered 318 refugees, Árbenz and his family included, as well as other members of his government, an unusually long period. The military junta refused to grant the safeconducts they needed to leave the country. In those weeks the Embassy endured attacks from Guatemalans who protested against the Mexican ambassador, Primo Villa Michel. He was accused of keeping the doors of the Embassy shut to anti-Communists who were fleeing repression when Árbenz was still in office.

The Guatemalans in the Mexican embassy, Árbenz in particular, were a cause of embarrassment for President Ruiz Cortines. The Guatemalan's presence associated the Mexican government with an enemy of the United States. The economic situation in Mexico was difficult; in April the government had announced a devaluation of the Mexican peso that went from 8.65 per dollar to 12.50 per dollar. The US government support had been crucial for stabilizing the exchange. The time did not seem right for a confrontation with the US.

Moreover, the main Mexico City newspapers complained about Árbenz' presence in the Mexican embassy, they even questioned the country's tradition of political asylum. For instance, "Refugees and felons" titled $\mathrm{El}$ Universal the editorial of July 5, 1954. According to the paper, Guatemalan refugees were "political extremists" who had engaged in criminal actions in their own country. The government had to be careful not to admit them into Mexican territory where, in all likelihood, they would provoke disorder and would try to disseminate their "dangerous ideas" (El Universal, 5/ 07/ 1954). In mid-July an incident revealed the government's will to 
differentiate itself from the Communists. The director of the Instituto Nacional de Bellas Artes, INBA, Andrés Iduarte, was ipso facto dismissed because he allowed a Communist flag to be placed on the casket of Frida Kahlo, the painter and wife of the renowned artist Diego Rivera, a Communist himself. The gesture was important because it took place in an official ceremony, in which Kahlo's remains were exposed to the public.

The diplomatic relation between Mexico and Guatemala was not interrupted. On July 13, Colonel Castillo Armas received the Mexican Ambassador Primo Villa Michel. This visit was an implicit acknowledgement of the new government, founded on the Estrada Doctrine that recognizes the right of nations to maintain or substitute their government, without the need for the international community to explicitly recognize its legitimacy.

In September, in his annual address to Congress, President Ruiz Cortines briefly mentioned the Guatemalan crisis, and concentrated himself instead on the defense of self-determination. He also condemned Communism but there was no mention of the US intervention, instead Ruiz Cortines praised continental solidarity as a contributing factor to world peace (XLVIII Legislatura, 1966, IV: 544).

\section{The Mexican aftermath}

Árbenz'fall did not free the Mexican government from US pressures. Washington sought to prevent that the fallen Guatemalan receive the status of political refugee. On August 19, 1954, US ambassador Francis White presented the Mexican Undersecretary, José Gorostiza, a Memorandum containing his government's suggestions for the treatment of Guatemalan political refugees. The document has six points that can be resumed in one: Communists had to leave the country. The Mexican government could turn them in to the Guatemalan government. The Guatemalan courts had already judged them and sentenced them for a number of serious crimes, or they could be sent to the country of their choice in the Soviet bloc (AGE, SRE, Correspondencia de la Embajada de E.U.A. 19/ 08/ 1954).

Such a proposition must have shocked and surprised the Mexican diplomat. In Mexico the Ministry of Foreign Relations was fully committed to the defense of political asylum and this tradition was obstinately upheld by the minister Padilla Nervo and by Isidro Fabela, a prominent jurist that at the end of the war was elected judge at the International Court of Justice. The US' ambassador's plan was ignored by the Ministry. Besides, the Guatemalan refugees had the support of the Sociedad de Amigos de Guatemala, most of whose members were also members of the PCM. ${ }^{35}$ Former President Cárdenas, may even have some of them as his guests in Mexico when they were finally released in October. ${ }^{36}$

President Ruiz Cortines grew impatient with the Guatemalans in the Embassy. On October 8, Undersecretary Gorostiza received a Memorándum from Ruiz Cortines private secretary with an underlined header: "By presi- dential instruction". The first line stated: "It is in the urgent interest of the Mexican Sate and of the Mexican people, now more than ever, to extradite the Guatemalan citizen Rosenberg (who had been Árbenz chief of police). Extradition has been requested on the grounds of criminal charges. It should proceed immediately." (AGE, SRE, "Correspondencia entre la Secretaría de la Presidencia y la SRE”, 08-11/ 1954).

The document refers to the President's exclusive prerogative to grant political asylum and to sign extraditions. In its most revealing passage the President's order describes the risks that he perceived in the refusal of the US government's request:

The United States of America wants Latin American governments to prove with undisputed facts that they stand against international Communism sponsored by the Soviet Union. Otherwise, internal unrest will suddenly appear and not cease until Communism has been totally banished from the Americas, on account of this region belonging de facto to the United States' political and economic sphere of influence (AGE, SRE, 08-11/ 1954).

Here President Ruiz Cortines expressed his major fear: "internal unrest", that could be a coup d'état, or a military uprising, something similar to the Guatemalan recent crisis. Thus, pressures on Mexico were predominantly political, probably because economic sanctions could hurt US interests as much as Mexico's. These interests had become so important that it was preferable to leave them undisturbed. The presidential Memorandum refers to the extradition of Major Rosenberg as a precedent "of a legal and anti-Communist nature in order to save Mexico from U.S. anti-Communist reprisals and distrust." (AGE, SRE, "Correspondencia entre la Secretaría de la Presidencia y la SRE”, 08-11/ 1954).

\section{RESTLESSNESS IN MEXICO: A GUATEMALAN LEGACY?}

The three remaining years of Ruiz Cortines' term of office, were a time of anxiety for the government. Students, workers and peasants protested, demonstrated on the streets, went on strike, occupied private farms, and attempted to organize independently from the PRI. Between 1955 and 1958 the number of strikes went from a 135 to 740; Rubén Jaramillo, an agrarian leader in the state of Morelos, led an armed group demanding land distribution. In 1956, students from the Instituto Politécnico Nacional, an institution created by President Cárdenas in 1937, challenged the government's restrictive economic policies and went on strike. However, the army took control of the Institute's buildings for a year until normality was restored. In 1958 members of the Communist party were elected to the railroad's union leadership as well as to the leadership of the teacher's union. Each of them attempted to break away from the PRI; however, their actions were shut down by the police, the leaders were arrested and remained in jail for several years. President 
Ruiz Cortines repeatedly reminded public opinion that he "would keep peace [throughout the country] at whatever price" (XLVIII Legislatura, 1966, IV: p.562).

At the same time, the Mexican President reinforced the PRI. In 1953 women's right to vote was recognized. The party launched an ample affiliation campaign and by 1955 , it announced that party membership had grown by three million. In the Presidential election of 1952 it won 2.7 million, but in the mid-term elections, the PRI received 90 per cent of the vote or 5.5 million votes. This figure indicates that according to the party's calculations it captured the totality of new voters (Singer, 2010: 138-169).

In August 1955, the US ambassador to Mexico, Francis White wrote President Eisenhower a letter describing the excellent relation he had developed with the Mexican president since the Guatemalan crisis (FRUS, 1955-1957: 680). White reported that until then Ruiz Cortines had not been friendly with him, but after Arbenz' fall, the President invited him to an informal conversation. Since that day his visits to the presidential residence at nightfall had become a weekly routine. It did not seem to cross White's mind that this shift in attitude of the Mexican President might have been related to the fear provoked by the coup against Arbenz. Several Latin American governments and Ruiz Cortines' among them thought the same could happen to them. According to White, the change was due to the "stable elements" of Mexican society - bankers, the chambers of industry and commerce, and segments of the middle classes - had reacted against the peso devaluation, but, most of all against the support for the Árbenz government. In his opinion the conservative opposition had been more influential than the left (Buchenau, 2004: 133).

White boasted of having convinced the Mexican President that Communism posed a genuine threat to Guatemala and Mexico. So much so, he continued, that Ruiz Cortines had proposed to further the cooperation between the two governments to fight Communism (FRUS, 19551957: 681). He also asked him to be discreet about their frequent exchanges. If they became public they could harm the government. Mexican public opinion was always distrustful of collaboration with the United States, ${ }^{37}$ especially in security matters. Paradoxically, the Presidential request revealed a lack of trust in the US that escaped the Ambassador's judgment.

The US may not have interfered directly in Mexican domestic affairs. However, it put an indirect pressure that was merely suggested. Presidents Eisenhower and Ruiz Cortines met for a third time in White Sulphur Springs on 26-27 March 1956. There Eisenhower made some suggestions to Ruiz Cortines. He told him that "subversion" and "Communist infiltration" were a matter of serious concern for the US people. He did not directly ask him to break up diplomatic relations with the Soviet Union, but he warned the Mexican president that all Soviet embassies were "centers of espionage, sabotage and subversive activities." 38 Ruiz Cortines agreed with his host on the need to reinforce the anti-Communist crusade. For Eisen- hower this commitment seemed to be a necessary introduction to any conversation with his allies. After that they proceeded to discuss trade and issues related to bilateral cooperation. ${ }^{39}$

By 1957 Ruiz Cortines had learned how to deal with Eisenhower's obsession with Soviet expansion and the dissemination of Communism. He understood that AntiCommunism guided the US President's perception of the world and of his responsibilities as leader of the free world. Anti-Communism provided also the standard by which he measured the loyalty of his country's allies. Ruiz Cortines understood that he could use the US President's concerns in Mexico's benefit. In the conversation the Mexican President had with the new US ambassador, Robert C.Hill, he thanked him for keeping their meetings confidential and for respecting Mexico's self-determination. Ruiz Cortines stressed the importance of non-interference by external powers in the presidential succession.

That day the last part of the conversation was dedicated to a description of Adolfo López Mateos'virtues. He was the PRI candidate for the presidency and his campaign had just started. Ruiz Cortines wanted to give the US government all reassurances that he and his successor were alike. He said: "He is exactly like me." "He knows how to treat Communists", "As I do", he added sibylline. ${ }^{40}$

\section{EPILOGUE}

As the presidential succession in 1958 approached, President Ruiz Cortines decided to offset the destabilizing effect of political discrepancies within society. The first step in that direction was to concentrate in his hands the decision regarding the PRI presidential candidate. López Mateos'candidacy was not the result of a negotiation among relevant political actors. He was chosen by Ruiz Cortines alone, who put in display all Presidential power. Secondly, he concentrated all his political energies in the building of an ample coalition comprising all those who identified with the Mexican Revolution, left and right. As a result López Mateos had the backing of Lombardo's Partido Popular Socialista, PPS, and of the retiree military members of Partido Auténtico de la Revolución Mexicana, PARM. Ruiz Cortines wanted López Mateos to represent revolutionary unity. Therefore, in July 1958 the PRI-PPS-PARM candidate - candidate of all revolutionaries - Adolfo López Mateos, had only one competitor - Luis Alvarez - the PAN candidate, who represented the adversaries of the Mexican Revolution. The 1958 election was the first one since 1940 that did not split the political elite. Nevertheless, rather than expressing agreement, the election showed the government's growing intolerance of dissent, and the weak institutional representation of political differences.

To what extent was this particular development in Mexican domestic politics a result of the cold war context? The answer to this question suggests that the political status quo in each Latin American country was connected to the regional order. The comparison between the 
Guatemalan experience of 1954 and the Cuban revolution a decade later indicates that the hemispheric order also contributed to sustain national political systems.

In a stable regional order, such as that prevailing in Latin America in 1954, domestic reforms were neither threatening to that order or to US hegemony, nor could they go very far. Whereas the transformation of the environment brought about by the instability of US-Soviet relations in 1961-1962, produced the setting of a Communist regime in Cuba and destabilized almost every other country in the region. This means that while national political systems are sensitive to changes in the external context, changes in the domestic context do not necessarily affect the regional order. However, for President Eisenhower and his Secretary of State, John F. Dulles, the preservation of the internal status quo - even if it was undemocratic - in Latin American countries was a condition for the continuity of the regional order. From their perspective the durability of these political systems was of strategic interest for the US. However, history proved them wrong, because the disruption of the regional order caused by US intervention overturned the internal order of things.

\section{ACKNOWLEDGMENTS}

I would like to thank Ana Covarrubias, Susan Eckstein and Ariel Rodríguez Kuri for their thoughtful comments on a first version of this article.

\section{NOTES}

1. Archivo Manuel Gómez Morín, (AMGM) Instituto Tecnológico Autónomo de México, ITAM, Partido Acción Nacional, Sección A.N. Subsección Organización, Comité Ejecutivo Nacional. Correspondencia, Expediente 163.

2. Louis Halle at the closing of the Xth Inter-American Conference in Caracas, Venezuela. In: Rabe, (1988: 53)

3. "Religion: rebirth in Mexico", Time, 09/May 1955 www.time. com/subscriber/article/0.33009.861455-2.00.html] [Accessed $21 / 11 / 2014]$

4. Russian archival documents show that the Comintern found in Vicente Lombardo Toledano "a herald of the Popular Front tactic more valuable than the Mexican Communist Party..."Victor y Lázar Jeifets, (2010: 53)

5. NACP, Md., CIA, Information Report- Secret, 15/March/1949. CIA-RDP8200457R00560012-5,p.3-

6. NACP, Md., CIA, Information report-Secret, 15/March/1949. CIA-RDP8200457R00560012-5,p.2.

7. Corporation for Economic and Industrial Research, United States-Latin American Relations, (1960: 25)

8. In 1949, the CIA Report sustained that in 1948, a number of conspicuous Latin American Communists had met in México: Blas Roca, Juan Marinello and Ladislao Carbajal, from Cuba, Salvador Ocampo from Chile, Celso Nicolás Solano from Panama and Manuel Mora Valverde from Costa Rica. They had contacted Narciso Bassols and former president Lázaro Cárdenas. To this groups'activities should be added the campaign organized by the Spanish Communist Party, that had an intense anti-US campaign. NACP,Md. CIA, Information Report. Secret, 15/ March/ 1949. CIA-RDP8200457R002400560012-5,:7.

9. In 1949, the CIA Report sustained that in 1948, a number of conspicuous Latin American Communists had met in México: Blas Roca, Juan Marinello and Ladislao Carbajal, from
Cuba, Salvador Ocampo from Chile, Celso Nicolás Solano from Panama and Manuel Mora Valverde from Costa Rica. They had contacted Narciso Bassols and former president Lázaro Cárdenas. To this groups'activities should be added the campaign organized by the Spanish Communist Party, that had an intense anti-US campaign. NACP,Md. CIA, Information Report. Secret, 15/ March/ 1949. CIA-RDP8200457R002400560012-5,: 21.

10. In 1949, the CIA Report sustained that in 1948, a number of conspicuous Latin American Communists had met in México: Blas Roca, Juan Marinello and Ladislao Carbajal, from Cuba, Salvador Ocampo from Chile, Celso Nicolás Solano from Panama and Manuel Mora Valverde from Costa Rica. They had contacted Narciso Bassols and former president Lázaro Cárdenas. To this groups'activities should be added the campaign organized by the Spanish Communist Party, that had an intense anti-US campaign. NACP,Md. CIA, Information Report. Secret, 15/ March/ 1949. CIA-RDP8200457R002400560012-5,: 21.

11. For instance, former President Cárdenas writes in his diary on May 9, 1958 that he had sympathy for the teachers in strike. In his Obras completas Cárdenas makes a number of references to similar situation with each con cada uno de sus sucesores, desde Miguel Alemán hasta Adolfo López Mateos. Lázaro Cárdenas (1973b: 39)

12. By 1954 Latin Americans' expectations of US'economic support had been disappointed at every Inter-American meeting: the Chapultepec conference in 1945, in Bogotá in 1948 and in Caracas in 1954.

13. Public investment registered modest increases in the first three years of the Ruiz Cortines administration: from 1354 millions of pesos in 1953 to 1661 millions of pesos in 1957. By contrast, foreign investment grew spectacularly in those same years from 40 thousand dolls. to a 131 thousand. Instituto Nacional de Estadística, Geografía e Informática, (1985, I: 602-610)

14. NACP,Md. CIA. The World Peace Conference, Report., May/1954 CIA-RDP 78-00915R000300040001-3.

15. "Lo que importa a Cárdenas es la conspiración internacional de siniestra.”, La Nación, (20 / 06/ 1954, XXVI, 662: 3)

16. Cárdenas writes in his notes that during the Guatemalan crisis he resigned from the position he held as Director of an energy supply project. The attacks against him were so violent that he feared they would end up damaging the government. President Ruiz Cortines did not accept the resignation and advised Cárdenas to ignore all comments. Finally, at the end of May the President publicly acknowledged and thanked Cárdenas for all services to the motherland. Lázaro Cárdenas, (1973a: 372-373)

17. A 1945 document signed by the Joint Chiefs of Staff was included in the conclusions of the Chapultepec Conference. It stated that the Western hemisphere was a "distinct military entity", and its integrity vital to the US security. Leffler, (1984): 354. In US military academies, cadets were taught the three imperatives of relations with the outside world: American territories were closed to further colonization by European powers; the US would not involve itself in European wars; and any "European attempt to spread its political system to the hemisphere was considered dangerous for the safety and peace of the United States" Smith, (1994: 3). In October 1962, in the middle of the missile crisis, Congressman John J.Rhodes from Arizona declared: "The Monroe Doctrine, which every member of this body was taught as a child in school is as sacred to the American tradition as the Constitution and the Declaration of Independence." Smith, (1994: 4).

18. The same type of restrictions had weighed upon the Mexican governments at the end of the nineteenth century. Friedrich Katz shows how Porfirio Díaz and his "científicos" (technocrats) lived in constant fear of the threat posed to their country's independence by their powerful neighbor to the north. Two types of phenomena could trigger an act of intervention by the United States: internal instability that threatened its interests in Mexico, and a commitment to another foreign power. Katz, (1981: 27-28) 
19. Manuel Tello, Mexican Ambassador in Washington reported to secretary of Foreign Relations Luis Padilla Nervo, on the visit of former Mexican president Abelardo L.Rodríguez to president Eisenhower. According to him, the relations he wished to cultivate with Mexico [and Canada] were not the same as with other countries in Latin America. "Geography has made us neighbors and we like it or not (his own words) this is a fact that inevitably marks our relations." Embajador Manuel Tello al C.Lic. Luis Padilla Nervo, Secretario de Relaciones Exteriores, 04/ 08/ 1953, 111/321.2 (42’73) 23783, Archivo Genaro Estrada, AGE, Secretaría de Relaciones Exteriores, SRE, México.

20. A February 1952 Memorandum from the US Ambassador in Mexico, William O'Dwyer, reveals the support Washington was prepared to give the Mexican government to maintain the status quo. The previous January, the two countries began negotiations that would eventually lead to a military agreement. After weeks of endless discussions the Mexican ambassador, Rafael de la Colina, explained that it was difficult for the government to sign such an agreement in the middle of a presidential campaign. The Alemán government had already been accused of selling out to the US. De la Colina's advice was to postpone the discussion after the election. By then political atmosphere in Mexico would have improved and the PRI would be stronger. His proposal was accepted. Ambassador Rafael de la Colina and Ambassador O'Dwyer "Memorandum of conversation." February 20, 1952. Cit. in "Editorial note", Foreign Relations of the US. The American Republics, 1952-1954, Vol. IV, Document 572, p.1330. http://history.state.gov/hisotricaldocuments/frus1952-54v047pg1330.

21. "Memorandum by the Secretary of State to the President" 13/ October/1953 (FRUS, 1952-1954: 1351)

22. John Foster Dulles' grandfather, John Watson Dulles, was Ambassador to Mexico from 1873 to 1880 . His son, John W.F.Dulles (1913-2008) author of Yesterday in Mexico, lived and worked in Mexico for almost two decades, in the 1950s and 1960 's and became a leading expert in the country's history.

23. "The Americas: the problem of Guatemala" Time, 11/ 01/ 1954 http://content.time.com/magazine/article/09171.819331.00.htm [Accessed 07/10/2014]

24. At the Caracas conference the OAS was an instrument of the US. The Mexican diplomacy was frustrated and decided to present its position in purely juridical terms. "Mexico has abstained from referring to the political problems weighing on the continental landscape even at the most critical moments of inter-American relations", (Pellicer, 1965-1966: 290)

25. "[He] shocked many seasoned observers of Latin American developments. [He forced] the Conference to take a position uncongenial to the majority of the Latin American countries. [He] did it in a manner likely to lose friends and alienate the peoples of the southern part of the hemisphere." (Connell Smith, 1966:161). The Uruguayan representative declared that he had voted "without enthusiasm, without optimism, without joy and without the feeling that we were contributing to the adoption of a constructive measure." (Connell-Smith, 1966: 163).

26. Even the Mexican delegation was profoundly divided on the vote. Ambassador Jorge Castañeda de la Rosa, former Minister of Foreign Relations, attended the conference as a young advisor to the Mexican delegation. He was sent from Caracas to Mexico City to consult directly with President Ruiz Cortines, who decided the abstention. Castañeda de la Rosa interviewed by Robinson in: "México frente a la crisis de Guatemala en 1954", Nancy Robinson (1987) "México frente a la crisis de Guatemala en 1954". Boletin americanista, 37: 225232: 229

27. "The X Inter-American Conference was a turning point in the history of the OAS. It introduced the anti-Communism key as an argument for the Department of State to legitimize interventionism in other countries' domestic affairs. It explains Cuba's expulsion from the OAS in 1962, or later, the intervention in 1965 the Dominican Republic ...the Caracas conference is a key episode for the understanding of the onset of the cold war in Latin America." (Morgenfeld, 2010, 1-1: 75-97).
28. "Letter from the Ambassador in Mexico (White) to the President", Mexico City, 29/ 08/ 1955, http://history.state.gov/historicaldocuments/frus1955-57v06/pg_710 [Accessed 24/ 02/ 2012]

29. Tiempo, vol. XXV, 21/ 06/ 1954.

30. "Congreso Anti-Comunista", Tiempo, vol. XXV, núm. 631, June 7, 1954, pp.5-6, p.5. This Pro-Liberation was in all likelihood a response to the Sociedad de Amigos de Guatemala that had been founded in Mexico City in November 1953. It belonged to a larger network covering most of Latin America, sponsored by the Soviet Union. "Progress report prepared in the Department of State for the Operations Coordinating Board", 25/May/ 1954, Document 8, http://history.state.gov/historicaldocuments/frus/1952-54v04/d8 [Accessed 12/ 05/2014]

31. The descriptions of Arbenz' reactions to the invasion show a man belittled, cornered and isolated. Luis Cardoza y Aragón, a Guatemalan writer, member of the Communist Party, who used to support Árbenz left a cruel and reproachful profile of the President whose resignation he finds inexplicable: "How do you explain President Árbenz' resignation? This was his defense of national sovereignty? How could he take such a decision on his own? What was his justification? He did it as he would have sold a horse." (Cardoza y Aragón, 1956: 198)

32. "Memorandum of conversation", White Sulphur Springs West Virginia, 07/March/1956. Participants: the President, President Ruiz Cortines of Mexico. Lt.Colonel Vernon Walters" http:// history.state.gov/historicaldocuments/frus1955-57v06/pg_710 [Accessed 24/ 02/ 2012]

33. Among President Árbenz personal papers, a blind Memorandum was found, dated June 5, 1954, containing notes for a conversation with Guillermo Toriello. The author's name is not known, but it is clearly the work of someone familiar with Mexico-Guatemala relations. The document contains a list of advice and recommendations for diplomatic tactics to be employed in response to the US offensive. There are also many references to a "distinguished and very important Mexican," who could promote Mexico's involvement as a "friendly mediator." It also alludes to an interview with former President Cárdenas, who was "deeply concerned" by the harassment of the Guatemalan government, and who intended to help it however much he could. According to the CIA, the author of the Memorandum was Manuel Pinto Usaga, former Guatemalan consul in Mexico. Document no. 17, "From Árbenz' personal effects," NACP, Md., CIA-RDP78-00915R000400090003-5. José Steinsleger recounts that, in August 1954, at a chance meeting with the poet Luis Cardoza y Aragón, Cárdenas told him "We were betrayed." Unfortunately we do not know how he helped or who did the betraying. José Steinsleger, "Guatemala, 10 años de primavera y 60 de invierno de involución" La Jornada, 06/ 18/ 2014; http://www.jornada.unam.mx/2014/ 06/18/opinion/031a1pol (Accessed 07/ 10/ 2014).

34. "Les événements du Guatemala ont provoqué des vives réactions dans les milieux universitaires du Mexique» Le Monde, 07/Juillet/1954 http://abonnes.lemonde.fr/acces-restreint/archives/article/1954 [Accessed 05/ 07/ 2014]

35. www.foia.cia.gov/cites/default/files/docum conversions/89801/DOC_000914527.pdf [Accessed 28/07/2014]

36. According to Spruille Braden, the US diplomat former Ambassador in Argentina and undersecretary for Latin America (1945$1946)$ in the State Department, the Guatemalan refugees were all "fellow travelers and gangsters", and guests of Cárdenas in his estate in Michoacán. Spruille Brade, The Reminiscenses of Spruille Braden, Oral History Research Office, Columbia University, 1959, 3029, Third Part, vol.viii. Butler Library, Columbia University.

37. "Letter from the Ambassador in Mexico (White) to the President", Mexico City, 29/ 08/ 1955, (FRUS, 1955-1957: 681)

38. In 1956 only Argentina, Mexico and Urugay had diplomatic relations with the Soviet embassy. According to a document prepared a the US embassy in Mexico City,the Soviet representation was "disproportionate" to the USSR-Mexico relations. These concentrated on cultural exchanges, but most of the 
embassy's personnel came from the military branch of the USSR government. The document sustains that the embassy administered four big units of paopaganda, It also had the support of the Polish and Czech embassies. NACP,Md., Department of State, "Letter from Raymond G.Leddy, Counselor of Embassy, to Kenneth M.Crockett, Esq, Officer in charge of Mexican Affairs, Department of State. September 24, 1957. 611.12/9-2457.

39. "Memorandum of conversation", White Sulphur Springs, West Virginia, March 27, 1956, 2 p.m. Participants: The President, President Ruiz Cortines of Mexico. L.t.Colonel Vernon A.Walters, http://history.state.gov/historicaldocuments/frus195557v06/pg_710 [Accessed 24/February/2012.]

40. NACP. Md., Department of State From - ARA-Mr. R.R.Rubottom, to The Secretary, 611.12/12-2357.

\section{REFERENCES}

Barrett, David M (2011) “Sterilizing a 'Red Infection'. Congress, the CIA, and Guatemala, 1954", Central Intelligence Agency (US), https://www.cia.gov/library-center-for-the-study-of-intelligence/kent-csi/vol/44no5/html/44i5a03p.htm [Accessed 01/ 03/2015]

Blanton, Thomas S (2008) "Recovering the memory of the Cold War. Forensic history and Latin America". In from the Cold. Latin America's new Encounter with the Cold War, edited by Gilbert M. Joseph and Daniela Spenser. Duke University Press, Durham y Londres: 47-73.

Brandenburg, Frank Ralph (1964) The Making of Modern Mexico. Prentice.Hall, Inc., New Haven.

Buchenau, Jürgen (2004) "Por una guerra fría más templada: México entre el cambio revolucionario y la reacción estadunidense en Guatemala y Cuba". En Espejos de la guerra fría: México, América Latina y el Caribe, coordinado por Daniela Spenser. SRE, CIESAS, Porrúa, México: 119-149.

Cámara de Diputados, XLVI Legislatura (1966) Los presidentes de México ante la nación, 1821-1966. Talleres Gráficos de la Nación, México, 5 volúmenes.

Cárdenas, Héctor (1993) Historia de las relaciones entre México y Rusia. Secretaría de Relaciones Exteriores, Fondo de Cultura Económica, México.

Cárdenas, Lázaro (1973) Obras I. Apuntes 1941/1956. UNAM, Nueva Biblioteca Mexicana, México, 2 vols.

Cárdenas, Lázaro (1973) Obras. I- Apuntes 1957-1966. UNAM, Nueva Biblioteca Mexicana, México, 2 vols.

Cardoza y Aragón, Luis (1956) La revolución guatemalteca. Ediciones Pueblos Unidos, Montevideo.

Carr, Barry (1996) La izquierda mexicana a través del siglo XX. Ediciones Era, México.

Castañeda, Jorge (1956) México y el orden internacional. El Colegio de México, México.

Coleman, Kenneth M (1976) Diffuse Support in Mexico: the Potential for Crisis. Sage publications, London.

Cosío Villegas, Daniel (1986) Memorias. Lecturas Mexicanas Segunda Serie, 55, Joaquín Mortiz- SEP, Mexico.

Covarrubias, Ana (2008) "México y la Revolución cubana. La independencia de un país dependiente". En Ensayos de política internacional. Homenaje a Olga Pellicer. coordinado por Arturo C. Sotomayor Velázquez and Gustavo Vega Cánovas. El Colegio de México/Instituto Tecnológico Autónomo de México/ Centro de Investigación y Docencia Económicas, México: $25-46$.

Craig, Campbell y Frederik Logevall (2012) America's Cold War, The Politics of Insecurity. The Belknap Press of Harvard University Press, USA.

Cullather, Nick (2006) Secret History: The CIA 's Classified Account of its Operation in Guatemala, 1952-1954. Stanford University Press, Stanford, CA.

Department of State (1954) Intervention of International Communism in Guatemala. Greenwood Publishers, Westport, Conneticut.
Fenn, Peggy (1963) "México, la No-Intervención y la autodeterminación en el caso de Cuba". Foro Internacional, IV-1: 1-19.

Gaddis Smith (1994) The Last Years of the Monroe Doctrine. 1945 1993. Hill and Wang, New York.

García Ferreira, Roberto (2007) "El caso de Guatemala: Arévalo, Árbenz y la izquierda uruguaya, 1950-1971". Mesamérica, 49: 25-58.

Gleijeses, Piero (1992) Hope shattered. The Guatemalan Revolution and the United States, 1944-1954. Princeton, Princeton, New Jersey.

Gordon Connell-Smith (1966) The Inter-American System. Londres, Nueva York y Toronto, Oxford University Press.

Hove, Mark T (2007) "The Arbenz factor: Salvador Allende, U.S.Chilean relations and the 1954 U.S. intervention in Guatemala". Diplomatic History, 31 (4): 623-663.

Instituto Nacional de Estadística, Geografía e Informática, (1985) Estadísticas Históricas de México. INEGI-INAH, México, 2 volúmenes.

Jeifets, Víctor y Lazar Jeifets (2010) "Los archivos rusos revelan secretos: el movimiento de la izquierda latinoamericana a la luz de los documentos de la Internacional Comunista". Anuario Americanista Europeo, 8: 2221-3872.

Joseph, Gilbert, M. y Daniela Spenser, (editors) (2008) In from the Cold. Latin America's new Encounter with the Cold War. Duke University Press, Durham y Londres.

Knight, Alan (1994) "Cardenismo: Juggernaut or jalopy?”. Journal of Latin American Studies, 26 (1): 73-107.

Katz, Friedrich (1981) The Secret War in Mexico. Europe, the United States and the Mexican Revolution. University of Chicago, Chicago and London.

Keller, Renata (2012) "A foreign policy for domestic consumption. Mexico's lukewarm defense of Castro, 1959-1969". Latin American Research Review, 47 (2): 100-119.

Leffler, Melvyn P (1984) "The American conception of national security and the beginnings of the Cold War, 1945-1948”. The American Historical Review, 89 (2): 346-381.

Linz, Juan J (1978) "Teoría del régimen autoritario: el caso de España”. En Política y sociedad en la España del siglo XX, Stanley G.Payne editor. Akal editores, Madrid: 205-226.

Lombardo Toledano, Vicente (1954) Obra Histórica-Cronológica. Centro de Estudios Filosóficos, Políticos y Sociales Vicente Lombardo Toledano, México.

Loaeza, Soledad (1988) Clases medias y politica en México. La querella escolar 1959-1963. El Colegio de México, México.

Loaeza, Soledad, (2012) La restauración de la Iglesia católica en la transición mexicana. El Colegio de México, México.

Meyer, Lorenzo (2010) México y el mundo, Historia de sus relaciones exteriores, La marca del nacionalismo. El Colegio de México, México.

Morgenfeld, Leandro Ariel (2010) "El inicio de la Guerra Fría y el sistema interamericano. Argentina frente a Estados Unidos en la Conferencia de Caracas (1954)". Contemporánea, Historia y Problemas del siglo $X X$, vol.1: 75-97.

Ojeda, Mario (1976) Alcances y límites de la política exterior de México. El Colegio de México, México.

Patch, Chester J. y Elmo Richardson (1991) The Presidency of Dwight D.Eisenhower. University Press of Kansas, Kansas.

Pellicer, Olga (1965-1966) "México en la OEA". Foro Internacional, VI-2 (3): 288-302.

Pellicer, Olga (1968) "La revolución cubana en México". Foro Internacional, VIII-4: 360-383.

Pellicer, Olga, (1972) México y la revolución cubana. El Colegio de México, México.

Rabe, Stephen G (1988) Eisenhower and Latin America. The Foreign Policy of Anticommunism. The University of North Carolina Press, Chapel Hill and London.

Rabe, Stephen G (2012) The Killing Zone, The United States wages Cold War in Latin America. Oxford University Press, New York and Oxford.

Robinson, Nancy (1987) "México frente a la crisis de Guatemala en 1954”. Boletin americanista, 37: 225-232. 
Rodríguez Kuri (2008) "Los años maravillosos: Adolfo Ruiz Cortines". En Gobernantes mexicanos, coordinado por Will Fowler. Fondo de Cultura Económica, México, Tomo 2: 265 $-286$.

Sabino, Carlos (2007) La historia silenciada. 1944-1989, Revolución y Liberación. Fondo de Cultura Económica, México.

Servín, Elisa (2004) "Propaganda y Guerra Fría: la campaña anticomunista en la prensa mexicana del medio siglo". Signos Históricos, número 11: 9-39, Universidad Autónoma Metropolitana, Unidad Iztapalapa.

Sewell, Bevan (2008) "A perfect (Free-Market) world? Economics, the Eisenhower administration, and the Soviet economic offensive in Latin America". Diplomatic History, 32 (5): 841-878.

Sola Ayape, Carlos (2014) 'Contra las cortes de ultratumba' y la 'legalidad de opereta': escritores de la derecha mexicana y sus críticas al exilio republicano español.". En 1945, entre la euforia y la esperanza: el México posrevolucionario y el exilio republicano español, editado por Mari Carmen Serra Puche, José Francisco Mejía Flores y Carlos Sola Ayape. Cátedra del Exilio, Fondo de Cultura Económica, México: 273-304.

Spenser, Daniela (1999) The Impossible Triangle. Mexico, Soviet Russia, and the United States in the 1920's. Duke University Press, Durham and Londres.

Spenser, Daniela (2010) "Vicente Lombardo Toledano envuelto en antagonismos internacionales". En Revolución y exilio en la historia de México, Del amor de un historiador a su patria adoptiva. Homenaje a Friedrich Katz, compiladores Javier Garciadiego y Emilio Kouri. El Colegio de México, Universidad de Chicago, Ediciones Era, México: 251-269.

Torres, Blanca (2010) México y el mundo. Historia de sus relaciones exteriores. De la guerra al mundo bipolar. El Colegio de México, México. 